\title{
The Expedition of Ilya G. Voznesensky to Russian America in 1839-1849 and the Formation of the American Collections in St. Petersburg Academic Museums ${ }^{1}$
}

\author{
Tatyana Yurievna Feklova \\ Department of History, \\ Institute of the History of Science and Technology RAN, \\ St. Petersburg Branch \\ Universitetskaya nab 5/2, \\ St Petersburg 199034, Russia \\ E-mail: tat-feklova@yandex.ru
}

\begin{abstract}
Expeditions were an integral part of the activity of the Russian Academy of Sciences, promoting its further development and prosperity. Expeditions also helped assemble data for future scientific development. In the first half of the 19th century, the territory of the Russian Empire included some regions of North America (Alaska, North California and the Aleutian Islands). The study of these areas was carried out with the participation of the Russian-American Company. The greatest merit for the scientific study of these regions belongs to a scientist from the Russian Academy of Sciences, llya G. Voznesensky. In this article, for the first time, attention will be paid to the analysis of organizational and documentary aspects of this expedition.
\end{abstract}

Keywords: expeditions, first half of the $19^{\text {th }}$ century, Ilya G. Voznesensky, Russian Academy of Sciences, Russian America

\section{Foreword}

The history of Russian America has been the main theme of a number of contemporary research projects. The three-volume History of Russian America, edited by Nikolai N. Bolkhovitinov (Istoriia Russkoi Ameriki, vols. 1-3) shows

\footnotetext{
This work was supported by RGNF grant no. 13-33-01232.
} 
the history of the Russian Empire's conquest of such territories as California, Alaska and the Aleutian Islands. The books cover the activities of the RussianAmerican Company, including the organization of research expeditions. This work involves a large number of different sources, most of which were previously unavailable to researchers.

The history of the individual expeditions in Russian America and their organizational features have not been studied in detail. Some of the problems surrounding the organizational side of the expedition have been described by Aleksey V. Postnikov (1998) in his article on the expeditions of Lavrenty A. Zagoskin, although it does not describe the organizational process in detail.

The life and research of the great scholar of Russian America Ilya G. Voznesensky (Fig. 1) have not been fully evaluated by historians. There are not many published books about this great scientist. The earliest discussion of Voznesensky was in an article by the academician Alexander Strauch (1832-1893), devoted to the jubilee of the Zoological Museum (Strauch, 1890). Other brief discussions of Voznesensky have appeared research papers on the history of North America, Alaska and California (Liapunova, 1967, pp. 5-33; Vekhov, 2006, pp. 24-31; Feklova, 2010, pp. 42-54). The most complete work to date is Alexander I. Alekseev's (1977) monograph Ilya Gavrilovich Voznesensky. Based on rich archival materials it gives a full description of his route and a detailed scientific analysis of the diary which Voznesensky kept during the entire trip. The author has paid attention to the companions of the scientist—Filat Druzhinin, Lavrenty Zagoskin, and others.

Some aspects of Voznesensky's expedition were considered in an article by Elena A. Okladnikova (1983, pp. 224-239) and in the monograph by Alexander I. Alekseev (1987). The history of Russian America, particularly the history of Alaska, has attracted foreign researchers as well, including Harry Ritter, Morgan B. Sherwood, and others. They have touched upon Voznesensky's expedition not as a complex investigation of the territory, but only in terms of a few of its scientific aspects. Especially noteworthy is the work of such researchers as Annetta M. Carter (1979, pp. 27-33) and B. A. Lipshits (1950). Lydia T. Black's Russians in Alaska, 1732-1867 deals with the history of the development of Russian America. Drawing on extensive archival research and using previously unavailable documents, Black shows the complexity of the relationship between the Russian people and Native Americans. She focuses on the study of intertribal marriages and on the contribution made by Native Americans and Métis to the development of Alaska, including in the course of their expeditions. 
The principal sources on this topic include materials from the St. Petersburg Branch of the Archive of the Russian Academy of Sciences (SPF ARAN, 1839-1848; $1839 \mathrm{~b})$ and the Russian State Historical Archive (RGIA, 1802-1839, p. 95). Sufficient attention has not been paid to such features of the expeditions as funding and organization. These aspects reflect the position of the Academy of Sciences in the environment of the state institutions of the Russian Empire. The study of the organizational side of expeditions also reflects the problem of the relationship between science and government. This approach to the interpretation of history of the expeditions of the Academy of Sciences is applied here for the first time.

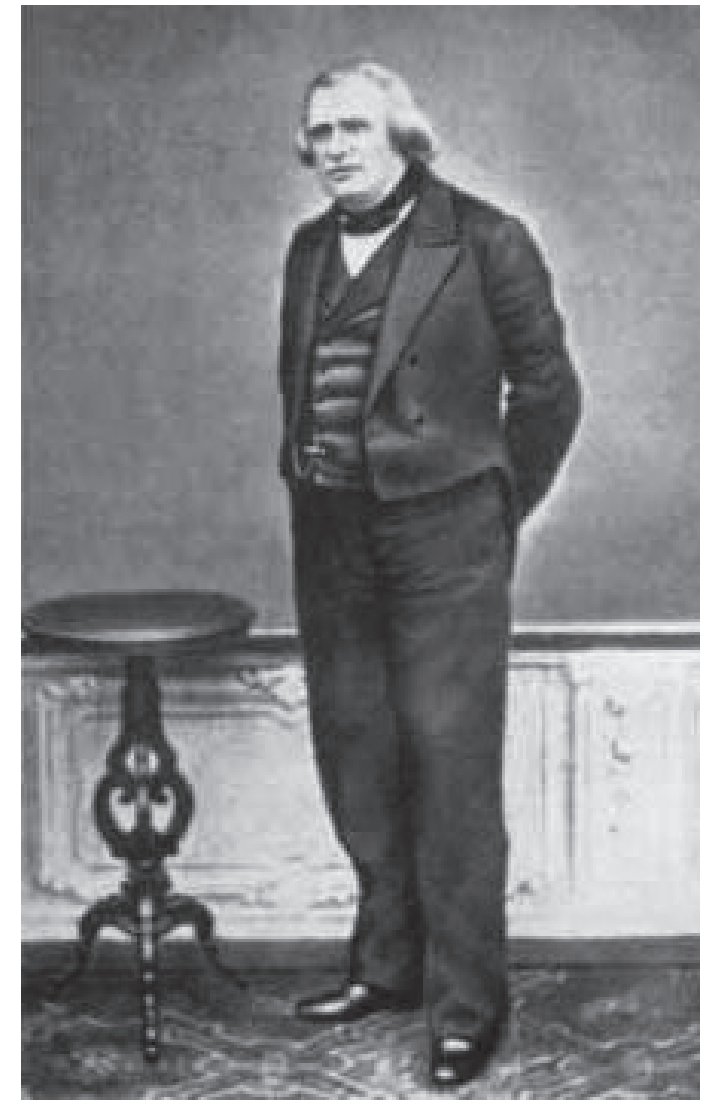

Figure 1. Ilya Gavrilovich Voznesensky (Vekhov, 2006).

\section{General organizational aspects of the expeditions}

Expeditions were complex multi-component interventions that needed to solve a diverse set of problems, including not only travel, gathering of collections and so on, but also the lengthy preparatory work they required. Organizational work before the expedition was an essential part of the expedition's activities. Securing permits and preparing estimates and instructions could take more time than the expedition itself. 
In the first half of the $19^{\text {th }}$ century, the government of the Russian Empire was reorganized into a set of powerful ministries (Predtechensky, 1957). The ministries adopted the principle of unity of command. Decisions were made by one person (the Minister), and then (if necessary) transferred to the Emperor (Prikhodko, 2002, p. 24). This simplified records management and sped up decision making. The preparation and conduct of the expeditions can be divided into several organizational steps: initiative, organization, the work itself, as well as a concluding phase. Each step was accompanied by a different set of documents.

A scientist had to prove the need for an expedition and provide an estimate of the expedition's costs. The Emperor made the decision about whether an expedition could depart. He also sent an order to the State Treasury for the appropriation of funds and also to other authorities, who were to provide assistance to the expedition's participants. These procedures usually lasted about half a year. Thus a plan for a summer expedition needed to be submitted the previous autumn. In addition, for an expedition to be financed by the State Treasury, the expedition had to be included in the budget of the following fiscal year.

Due to the rigid regulation of records management in the Russian Empire in the $19^{\text {th }}$ century, the correspondence between the ministries and the Academy of Sciences was extremely multifaceted and all-encompassing. Any question concerning the expedition demanded written confirmation and clarification. The work of collaborative expeditions between the Academy of Sciences and the Navy Department, the War Ministry, or the Russian Orthodox Church and other authorities could define the nature of interaction between organizations in the Russian Empire.

Each expedition was equipped with its own complex of supporting documents. These collected documents depended on the goals and tasks of the expedition. The supporting documents helped scientists to better carry out their tasks. Among these documents were open letters, ledgers, letters to tribal leaders, etc. Open letters were the prototype of modern travel documents. The route and purpose of the expeditions were described in the open letters, which instructed local administrators to render all possible assistance to the expedition. Organizational correspondence is often not confined to the level of the Emperor, the ministries and the Academy of Sciences. Even as the expedition was underway, the ministries, the Emperor, and the Academy continued to send out regulations, letters, and orders to local officials. For example, during Voznesensky's expedition to Russian America in 1839-1849 the board of directors of the Russian-American Company (henceforth RAC) ordered its local managers to advance the scientist 
The Expedition of Ilya G. Voznesensky to Russian America in 1839-1849 and the Formation of the American Collections in St. Petersburg Academic Museums

weapons from the company's stores, payable from the accounts of the Academy of Sciences (Vekhov, 2006, p. 24). The Voznesensky expedition provides an ideal case study of the organization of expeditions in the $19^{\text {th }}$ century.

\section{Research on the territory of Russian America in the $19^{\text {th }}$ century}

At the turn of the $19^{\text {th }}$ century, the Russian Empire included, besides its vast territories in Europe and Asia, American lands: Alaska, Northern California and the Aleutian Islands (Fig. 2). The history of charting the lands of Russian America began in the $18^{\text {th }}$ century, when Russian navigators and merchants began to reach the American continent. The RAC, organized in 1799 to trade with native peoples, supported the development and study of these territories. The activities of the RAC influenced the entire course of geographical studies in Russian America.

With assistance from the Russian government, the RAC organized 25 expeditions, including 15 round the world (headed by Ivan F. Krusenstern (1770-1846), Yury F. Lisianski (1773-1837), and others). These expeditions carried out active investigations into the ethnography and geography of Russian America. However, the expeditions that were organized by the RAC included only small regions of Alaska, California or Kamchatka. The most famous expeditions, which investigated the central part of Alaska, were those organized by researchers of Russian America such as K. T. Khlebnikov (1776-1838), F. L. Kolmakov (1770-?), A. K. Glazunov, I. Ya. Vasilev, E. I. Veniaminov (1797-1879), and L. A. Zagoskin (1808-1890) (Istoriia Russkoi Ameriki, 1999, vol. 3).

Khlebnikov studied Russian America for 16 years. He repeatedly visited California, Alaska and the Aleutian Islands. He was the author of several articles about the geography and ethnography of these territories. In 1841-1843, Zagoskin studied the territories of Alaska. He was in the service of the RAC and was the captain of a ship. In 1841, Zagoskin undertook one of the last Russian voyages to California. The same year, California was sold. In Fort Ross (California), Zagoskin met Voznesensky, who taught him to collect biological and zoological specimens (Postnikov, 1998, p. 48).

In the spring of 1842, one of the directors of the RAC, Adolf K. Etholén (17991876), offered to prepare an expedition to the central part of Alaska, to the Kuskokwim and the Kvikhpah (the modern-day Yukon) rivers (Puteshestviia $i$ 
issledovaniia..., 1956, p. 23). Before Zagoskin's expedition, the interior areas of Alaska were examined by an expedition led by Ivan Ya. Vasilev. It was the first scientific expedition to the Kuskokwim River. In 1841, Zagoskin sent a letter to Ferdinand P. Wrangell (1796-1870), chief director of the RAC, in St. Petersburg. Wrangell approved the plan of his expedition and Zagoskin received detailed instructions. He had to investigate the hydrology of the Kuskokwim and Kvikhpah rivers, as well as stopping of trade between the Native Americans and the Hudson's Bay Company (HBC).

The total cost of the expedition was 6,475 rubles and $464 / 7$ kopecks. Astronomical instruments cost 561 rubles and 56 3/7 kopecks, goods 340 rubles and 60 kopecks. Weapons, food supplies, clothing, and various materials cost 150 rubles and 27 1/7 kopecks. The salary of the expedition's leader for two years and four months was 4,000 rubles. The award issued to the head of the expedition from the main board of the RAC was 1,714 rubles and $284 / 7$ kopecks. The award, given to the team from the main board of the Company was 182 rubles and 85 5/7 kopecks. The total amount received was 7,130 rubles and 57 1/7 kopecks. (Puteshestviia $i$ issledovaniia..., 1956, p. 49). The Zagoskin expedition was important for the study of the central regions of Alaska. The main products of the expedition were a map of Alaska, an ethnographic collection, and a dictionary of the Athabaskan languages.

\section{The Voznesensky expedition}

The RAC's expeditions pursued utilitarian aims, because the company was interested, above all, in the expansion of its trading region. Thus the expeditions of Khlebnikov, Zagoskin and others were not, on the whole, scientific ones. They covered only a small region and could not represent the full picture of the nature and population of Russian America. As a result, only the academic expedition under the leadership of Ilya G. Voznesensky (1839-1849) included all the regions entering the sphere of influence of the RAC, and included studies in a variety of disciplines (botany, zoology, ethnography, geography, linguistics, and so on).

The first director of the Zoological Museum, Fedor F. Brandt, was the initiator of this expedition. In May 1839, he presented a plan for a scientific expedition in Russian America to the Conference of the Academy of Sciences and to the 
The Expedition of Ilya G. Voznesensky to Russian America in 1839-1849 and the Formation of the American Collections in St. Petersburg Academic Museums

President of the Academy Sergei S. Uvarov. The latter sent this plan to Emperor Nicholas I (1796-1855), who approved of the plan and ordered the issuance of funds and required documents. Etholén, director of the Russian-American Company in 1840-1845, provided additional support during the expedition on the territory of Russian America.

Questions about the organization of expeditions in the first half of the $19^{\text {th }}$ century were typically resolved within one to two months. For example, the Academy of Sciences had received a petition about the expedition of Alexander F. Middendorff on October 10, 1841. Emperor Nicholas I had given permission for its organization and financial support on November 19. A few days later, the expedition left St. Petersburg (RGIA, 1819-1835). At the beginning of this expedition, the Zoological Museum's curator E. I. Schröder wrote that researchers from other countries often visited Russian colonies and could display in their own museums objects from Russian America which were not presented in Russian museums. This fact also influenced the decision to send the expedition to Russian America. In June 1839, Uvarov (1786-1855), the Minister of Education and President of the Academy of Sciences, ordered an expedition to Russian America for zoological, biological, mineralogical, and ethnographic studies to be prepared. Ilya G. Voznesensky was appointed the leader of this expedition (Letopis' Rossiiskoi Akademii Nauk, vol. 2, p. 285).

Voznesensky was born in St. Petersburg in 1816. His father was an employee of the Academy of Sciences. In 1821, when Voznesensky was five years old, he was sent to the academy's print house to work as a typesetter. In 1832, Vosnesensky (then a 16-year-old boy) became an assistant to Édouard Ménétries (1802-1861), the curator of the Zoological Museum (part of the Imperial Academy of Sciences). As an assistant to the curator, Voznesensky participated in an expedition to the Caucasus in 1829-1830.

Despite the fact that Voznesensky's major area of research was Russian America, he made an almost around-the-world voyage. In 1839, on his first voyage aboard a ship of the RAC, he made a stop in Brazil and Peru. At the request of Brandt (1802-1879) Voznesensky had to collect biological and zoological specimens there. Before the trip, Brandt had advised Voznesensky to study the collections of the academy's museums to complement them during his expedition.

The main aims of this expedition were the ethnographic description of native peoples and the collection of zoological and botanical samples. The Academy of Sciences gave Voznesensky instructions, according to which he was entrusted 


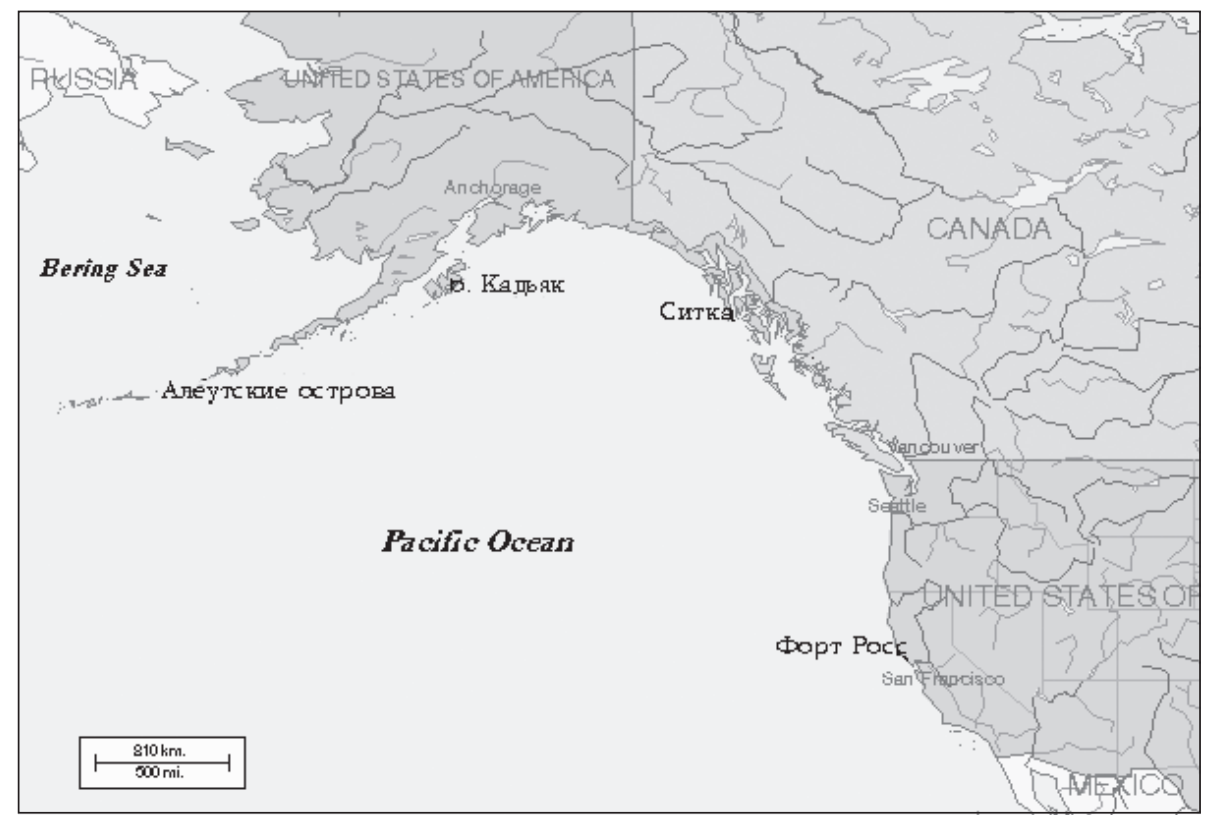

Figure 2. Russian colonial possessions in America (RAK, n.d.).

to collect native clothes; musical instruments; fishing implements; objects of daily use; axes, knifes and devices replacing them; idols; weapons, including spears, arrows, maces and so forth; manuscripts; pictures; as well as zoological and biological specimens and other objects of interest. Scientists of the Academy of Sciences had given special instructions in different branches of science for every scientist who embarked on the expedition. Such instructions were prepared also for the officers or members of missions who were not directly employed by the academy. Thus the Academy of Sciences received accurate and professional information about different counties from untrained and non-academic people. For example, special instructions were provided by the Academy of Sciences for the members of the around-the-world expedition of 1826-1829. Voznesensky had to teach local inhabitants to gather zoological, botanical and ethnographical collections (SPF ARAN, 1839a, p. 1).

The initial term of the expedition was set at three years, with a possible extension. The Academy of Sciences paid Voznesensky a double salary of 1,600 rubles a year (full academicians received 2,200 rubles per year), appropriating an additional 1,200 rubles a year for the acquisition of collections. Part of his salary (800 rubles) were allocated by the Botanical and Zoological museums (RGIA, 18021862). 


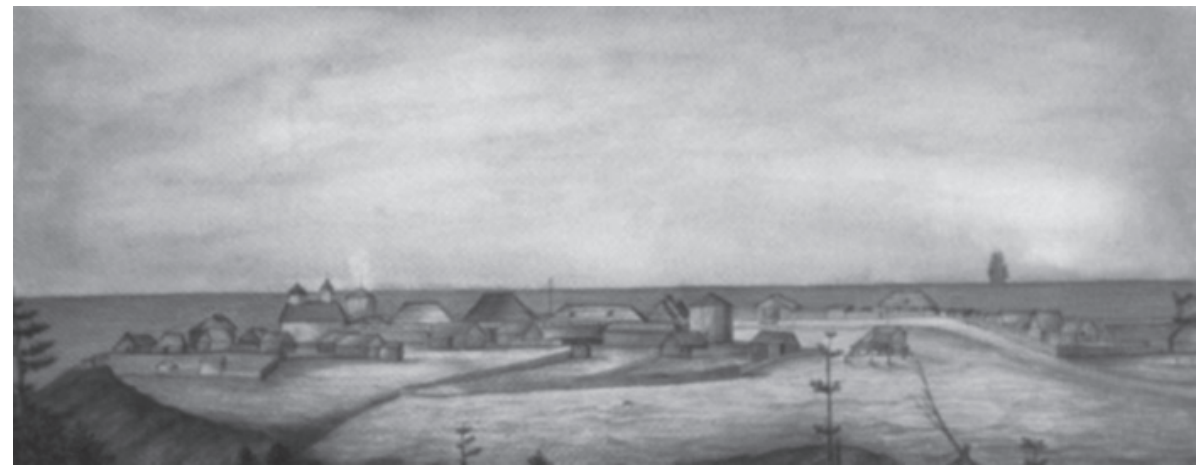

Figure 3. Water colour image of Settlement (Fort) Ross, painted in 1841 by llya Voznesensky. From the collections of Kunstkamera.

On August 20, 1839 Ilya G. Voznesensky departed for Russian America and in the spring of 1840 he arrived in Novoarkhangelsk, Alaska (modern-day Sitka) (Vekhov, 2006, p. 24). In 1840-1841, Voznesensky travelled around the outskirts of Fort Ross in California (Fig. 3). Here he managed to collect materials on the lives of California's Native American tribes, many of which were destroyed during the colonization of California by Americans. Among such objects were ritual capes made from the feathers of a condor and an eagle, currently on display at the Kunstkamera (St. Petersburg).

Voznesensky also had to develop bases for the systematic description of collections. He described samples from his ethnography collection in a special book (the prototype of a field journal). He described the material an object was made of, its use, and its ritual meaning (SPF ARAN, 1839c). This information was duplicated on individual label which was attached to the object. This work was very helpful for the further formation of collections in the academy's museums. For example, for the collection of insects in Northern California, Voznesensky created a color classification. Insects from Drake's Cape were designated by a square of red paper. Bluish-white square paper was used for insects from the shores of St. Francisco Bay. Green paper designated the insects from Khlebnikov Valley (SPF ARAN, 1839c). Insects marked only by numbers or with the application of the squares cut from plain cardstock were collected in the outskirts of Fort Ross at Bodega Bay. Squares of white tissue paper attached to insects were collected on an expedition to Mount St. Helens.

In 1842, Voznesensky went to Kodiak (Alaska), which came to serve as a base for the scientist. From this base he visited the lake of Kodiak, and in 1843 went 
north on the brig Okhotsk with the permission of Adolf K. Etholén, the governor of the Russian colonies. Voznesensky visited the islands of Unga, Unalaska, St. Paul, and St. George, the Mikhaylovsky Redoubt, different sites along the Bering Strait, on the Asian coast, the Mechigmensk Gulf and Kotzebue Bay. During this voyage, he collected more than one hundred ethnographic objects from the various tribes of Native Americans and others from the Inuit of Kotzebue Bay and of the Yukon and Kuskokwim rivers (Alekseev, 1977, p. 42). Etholén wrote to Voznesensky that he could send his package on the ships of Hudson's Bay Company (SPF ARAN, 1839b, p. 30).

The Creole (Métis) Filat Druzhinin helped Voznesensky during the expedition and became a faithful assistant to the scientist. Druzhinin, following Voznesensky's instructions, independently studied some of the Aleutian Islands (St. Paul, Unalaska, and others). An open letter (an analogue of the modern mission order), issued to Voznesensky, prescribed that the scientist could request necessary funds from the RAC. The letter specified the amount of funds to be issued, with further payments to be provided by the Academy of Sciences. At the same time, the RAC kept its own profits in mind. During the hunt, Voznesensky was allowed skins of the first class, but not of the superior grade, for taxidermy. The other furs he had to hand over to the RAC (SPF ARAN, 1839-1848). The researcher maintained contacts with the RAC with requests for assistance with the collection. In 1846, Voznesensky wrote to the office of the RAC that local fishermen should be asked to catch rare fish. Voznesensky also posted in the offices of the RAC a list of rare animals which were sought throughout Russian America. It was assumed that hunters would catch these animals and deliver to the Academy of Sciences, but the assumption proved unjustified (SPF ARAN, 1839a, p. 3). The RAC also provided the scientist with armaments. This was also spelled out in the open letter issued to Voznesensky by the RAC's board of directors. For example, in April 1844 the RAC gave the scientist a gun, which he pledged to return the next year.

The governor of Kamchatka, R. G. Mishin, issued Voznesensky an open letter, number 682, addressed to all native tribal leaders. It asked them to provide Voznesensky with any objects which might prove interesting to the scientist, and if he desired to examine the area near settlements, to provide him with a reliable guide (SPF ARAN, 1846-1848). The practice of issuing special documents which were addressed to native peoples was used in other expeditions, as well as in foreign countries. For example, during the expedition of E. P. Kovalevsky (1809-1868) to Egypt in search of gold in 1847, Muhammad Ali Pasha gave the expedition 
The Expedition of Ilya G. Voznesensky to Russian America in 1839-1849 and the Formation of the American Collections in St. Petersburg Academic Museums

a special firman (written order). According to this, every Egyptian citizen was ordered to assist the scientist on pain of death (Tsenkovskii, 1850, p. 3).

In the summer of 1844, Ilya G. Voznesensky visited the Kurils and Aleutian Islands. There he collected, in addition to everything else, two parkas made by the Aleuts of Atkha Island. Voznesensky had become friends with local merchants in Alaska, in the city of Novoarkhangelsk (Sitka). These merchants forwarded Voznesensky many objects of ethnographic interest, subject from Native Americans of Alaska. Some samples for collections the scientist bought himself and others were given to Voznesensky as gifts. A part of the samples, for example, a collection of tiny boats made by the Tlingits (one of tribes of Native Alaskans), Voznesensky ordered specially in Sitka (SPF ARAN, n.d.). In July 1844, Voznesensky found on Bering Island part of the skeleton of the extinct Steller's sea cow (Hydrodamalis gigas), which became a very valuable exhibit for the Russian Academy's Zoological Museum. In 1846, Voznesensky's expedition was extended. The scientist was issued 1,000 rubles from the State Treasury. In 1848, Voznesensky studied Kamchatka.

In 1849, Voznesensky returned to St. Petersburg on board a ship owned by the RAC. His collection took 38 seats. Voznesensky anticipated problems with customs on the border. He sent a letter to the Academy of Sciences with a request to solve the problem that if the customs office unpacked the items, it would lead to their deterioration. The Department of Foreign Trade allowed the collection to be examined in an academic museum in the presence of a customs officer (SPF ARAN, 1839b, p. 106).

Voznesensky's expedition continued for nine years and ten months. From this expedition he brought back 434 mammals, 2,859 birds, 179 fishes, 5 tortoises, 210 skeletons of mammals and birds, 1,052 ethnographic objects in 150 boxes, a herbarium on 2,000 sheets and a large geological-mineralogical collection (SPF ARAN, 1839b, p. 132). This geological-mineralogical collection, which was gathered in Russian America and on Kamchatka, was completely unsorted. Voznesensky's collections were transferred to the Zoological, Ethnographical (Kunstkamera) and Biological Museums.

Being mainly a zoologist, Voznesensky also collected ethnographic items. He collected masks, wares, and arms not individually but in series. At present, the Kunstkamera collections No. 571, 593, 620, and 868 are entirely the work of Voznesensky, along with a considerable portion of items in collections No. 570 and 2913. At the beginning of the $20^{\text {th }}$ century more than half of 
Voznesensky's collections were registered as "ancient receipts of a museum". Now a considerable part of these objects have been given proper attribution. Currently, the Voznesensky collection of ethnographic objects makes up a large part of Kunstkamera's North American Ethnographic Collection. These collections are widely used by modern historians and ethnographers.

After Voznesensky's return to St. Petersburg, he was appointed a second conservator of the Zoological Museum. In May 1852, Voznesensky was elected a corresponding member of the Russian Geographical Society. In 1856, he was awarded the Order of St. Stanislaus of the third degree. In 1859, Voznesensky became one of the founders of the Russian Entomological Society. He died in 1871.

\section{Conclusion}

The study of Russian America pursued, above all, utilitarian ends. Numerous expeditions organized by the Russian-American Company or with its participation sought to clarify the prospects for increasing fur trade. Among these are the expeditions led by such researchers as Lavernty A. Zagoskin, Ivan Ya. Vasilev, Feodor L. Kolmakov and others. At the same time, researchers were not limited only by utilitarian tasks. They mapped the territory, studied the hydrography of those regions and collected botanical, zoological, and ethnographic specimens. On the other hand, the inclusion of territories of Russian America in the economic activities of the Empire required their full and comprehensive study. From this point of view only the Voznesensky expedition represented an attempt at a full study of these regions. During the years of the expedition, Voznesensky explored Russian California, Alaska, the Aleutian and Kuril Islands, and Kamchatka. A few decades later, many of these areas were transferred to the United States. Thanks to the Voznesensky expedition, the Russian Academy of Sciences possesses the largest collection of ethnographic and natural-scientific objects from Russian America in the world. The study of the organizational side of expeditions helps to understand the mechanism of decision making in the Russian Empire in the first half of the $19^{\text {th }}$ century. It also shows the system of interaction between various institutions in the country and the role of the Academy of Sciences in this system. 
The Expedition of Ilya G. Voznesensky to Russian America in 1839-1849 and the Formation of the American Collections in St. Petersburg Academic Museums

\section{References:}

Alekseev, A. I. (1977), Ilya Gavrilovich Voznesenskii, Moskva: Nauka. (1987), The Odyssey of a Russian Scientist: I. G. Voznesenskii in Alaska, California, and Siberia, 1839-1849, Kingston, Ont., Canada: Limestone Press.

Black, L. T. (2004), Russians in Alaska, 1732-1867, Fairbanks: University of Alaska Press.

Blomqvist, E. A. (1951), 'Risunki I. G. Voznesenskogo' [Sketches of I. G. Voznesensky], in Sbornik Muzeia antropologii i etnografii [Collection of the Museum of Anthropology and Ethnography], vol. 13, pp. 230-303.

Carter, A. M. (1979), 'I. G. Voznesenskii, Early Naturalist in Baja California, Mexico,' Taxon, vol. 28, no. 1/3 (April), pp. 27-33. http://dx.doi.org/10.2307/1219552

Feklova, T. Yu. (2010), 'Ekspeditsiia preparatora Imperatorskogo Zoologicheskogo muzeia Akademii nauk I. G. Voznesenskogo v russkie vladeniia v Amerike' [Expedition of an anatomist of the Imperial Zoological Museum of the Academy of Sciences I. G. Voznesensky to the Russian possessions in America], in Voprosy istorii estestvoznaniia i tekhniki [Questions of the history of science and technology], vol. 1, pp. 42-54.

Gilzen, K. K. (1916), Ilya Gavrilovich Voznesensky. K stoletiyu so dnia rozhdeniia' [On the centenary of his birth], in Sbornik Muzeia antropologii i etnografii [Collection of the Museum of Anthropology and Ethnography], vol. 3, pp. 1-14.

Istoriia Russkoi Ameriki 1732-1867 (1999), [History of Russian America], Moscow: Mezhdunarodnye otnosheniia.

Letopis' Rossiiskoi Akademii nauk (2002), [Annals of the Russian Academy of Sciences], vol. 2, SPb: Nauka.

Liapunova, R. G. (1967), Ekspeditsiia I. G. Voznesenskogo i eio znachenie dlia etnografii Russkoi Ameriki' [Expedition of I. G. Voznesensky and its value for the ethnography of Russian America], in Sbornik Muzeia antropologii in etnografii [Collection of the Museum of Anthropology and Ethnography], vol. 24, pp. 5-33.

Lipshits, B. A. (1950), Etnograficheskie materialy po Severo-Zapadnoi Amerike v arkhive I. G. Voznesenskogo' [Ethnographic materials on North-West America in the archive of I. G. Voznesensky], Izvestiia Vsesoyuznogo Geograficheskogo obshchestva [Proceedings of the All-Union Geographical Society], vol. 82, no. 4, pp. 415-420.

Okladnikova, E. A. (1983), 'The California collection of I. G. Voznesensky and the problems of ancient cultural connections between Asia and America,' Journal of California and Great Basin Anthropology, vol. 5, nos. 1-2, pp. 224-239.

Postnikov, A. V. (1998), Ekspeditsiia L. A. Zagoskina 1842-1844 gg., eio znachenie i rezul'taty (k 50-letiiu publikatsii materialov)' [Expedition of L. A. Zagoskin and its value and results (by 50 years of publication of materials], in Voprosy istorii estestvoznaniia $i$ tekhniki [Issues in history of natural science and technology], Moskva: Nauka. 
Predtechenskii, A. V. (1957), Ocherki obshchestvenno-politicheskoi istorii Rossii v pervoi chetverti XIX veka [Essays of the social and political history of Russia in the first quarter of the $19^{\text {th }}$ century], Moskva: Izd-vo Akademii Nauk.

Prikhodko, M. A. (2002), Podgotovka i razrabotka ministerskoi reformy v Rossii (fevral' - sentiabr' 1802 g.) [Preparation and development of the ministry reform in Russia (February-September 1802)], Moskva: Kompaniia Sputnik.

Puteshestviia $i$ issledovaniia... (1956), Puteshestviia i issledovaniia leitenanta L. Zagoskinav Russkoi Amerike v 1841-1844 gg. [Travels and research of Lieutenant L. A. Zagoskin to Russian America in 1841-1844], Moskva: Gos. Izd-vo geogr. lit.

RAK (n.d.), 'Map of Russian colonial possessions in America' [Image]. Retrieved from http://alaska-heritage.clan.su/index/0-315 [accessed Oct 2014]

RGIA (1802-1862), Otchety nauchnykh uchrezhdenii, uchebnykh okrugov i universitetov; sborniki ukazov Senata (po otdel'nym uchebnym okrugam) za 1802-1862 gg., F 733, op 95, d 7-9, 1 3, Russian State Historical Archive, St. Petersburg.

(1802-1839), Dela po Akademii nauk: o peresmotre akademicheskogo ustava i shtatov, ob ekspeditsiiakh, nauchnykh komandirovkakh, uchebnykh puteshestviiakh, priobretenii kollektsii $i$ sobranii, ob izobreteniiakh, ob izdatel'skoi deiatel'nosti, ob izbranii $i$ utverzhdenii raznykh lits $v$ zvanii akademikov $i$ ad"iunktov, nagrazhdenii $i$ uvol'nenii ikh. za 1802-1839 gg., F 733, op 12, d 514, Russian State Historical Archive, St. Petersburg.

- (1819-1835), Lichnye dela sluzhashchikh tsentral'nykh uchrezhdenii MNP i upravlenii uchebnykh okrugov-materialy Sekretarskogo stola i 1 go stola Kantseliarii (s 1819 g.) za 1819-1835 gg., F 733, op 2, d 262, 1l 1-67, Russian State Historical Archive, St. Petersburg.

Russkaia Amerika (1994), Po lichnym vpechatleniiam missionerov, zemleprokhodtsev, moriakov, issledovatelei $i$ drugikh ochevidtsev [Russian America: On personal impressions of missionaries, explorers, sailors, scientists and other witnesses], Moskva: Mysl'.

SPF ARAN (n.d.), Voznesenskii Il'ia Gavrilovich (1816-1871), zoolog, entomolog, puteshestvennik, F 53, op 1, d 3/1-11, 1 12, St. Petersburg Branch of the Archive of Russian Academy of Sciences, St. Petersburg.

- (1839a), 'Instruktsiia, dannaia Voznesenskomu', Voznesenskii Il'ia Gavrilovich (1816-1871), zoolog, entomolog, puteshestvennik, F 53, op 1, d 1, ll 1, 3, St. Petersburg Branch of the Archive of Russian Academy of Sciences, St. Petersburg.

(1839b), Ob otpravlenii..., F 2, op 1, d 9, 11 30, 106, 132, St. Petersburg Branch of the Archive of Russian Academy of Sciences, St. Petersburg.

(1839c), Voznesenskii Il'ia Gavrilovich (1816-1871), zoolog, entomolog, puteshestvennik, F 53, op 1, d 3 1/9, 1 7, St. Petersburg Branch of the Archive of Russian Academy of Sciences, St. Petersburg.

(1839-1848), Voznesenskii Il'ia Gavrilovich (1816-1871), zoolog, entomolog, puteshestvennik, F 53, op 1, d 35, $131 \mathrm{ob}$, St. Petersburg Branch of the Archive of Russian Academy of Sciences, St. Petersburg. 
The Expedition of Ilya G. Voznesensky to Russian America in 1839-1849 and the Formation of the American Collections in St. Petersburg Academic Museums

(1840), Voznesenskii Il'ia Gavrilovich (1816-1871), zoolog, entomolog, puteshestvennik, F 53, op 1, d 36, St. Petersburg Branch of the Archive of Russian Academy of Sciences, St. Petersburg.

(1841-1848), Voznesenskii Il'ia Gavrilovich (1816-1871), zoolog, entomolog, puteshestvennik, F 53, op 1, d 39, St. Petersburg Branch of the Archive of Russian Academy of Sciences, St. Petersburg.

(1846-1848), Voznesenskii Il'ia Gavrilovich (1816-1871), zoolog, entomolog, puteshestvennik, F 53, op 1, d 19, 1 1, St. Petersburg Branch of the Archive of Russian Academy of Sciences, St. Petersburg.

Strauch, A. A. (1890), Zoologicheskii muzei Imperatorskoi Akademii nauk-Prilozhenie k LXI tomu "Zapisok Imp. AN", [Zoological museum of the Empire Academy of Sciences-Appendix to LXI volume of the "Memoirs of the Empire Academy of sciences"] no. 3, SPb: Zoologicheskii muzei.

Tikhmenev, P. A. (1863), Istoricheskoe obozrenie obrazovaniia Rossiisko-amerikanskoi kompanii i deistvii ee do nastoiashchego vremeni [A historical survey of education of the Russian-American Company and its operations from the past to present], Part 1 (1861), Part 2 (1863), SPb: Tip. E. Veimara.

Tsenkovskii, L. S. (1850), Otchet o puteshestvii v Severovostochnyi Sudan [Report on travels to Northeast Sudan], SPb: Geografiicheskie izvestiia.

Vekhov, N. (2006), Ili'a Gavrilovich Voznesenskii: (zoolog, 1816-1871),' Moskovskii zhurnal, no. 3, pp. 24-31.

Dr. Tatyana Feklova earned his first degrees in history from the State University of Petrozavodsk (2000-2005) and her PhD in history of science from the Institute for the History of Science and Technology, Russian Academy of Sciences (2012). She is research fellow at the Department of History, St. Petersburg Branch of the Institute of the History of Science and Technology, RAN. Dr. Feklova has been exploring the history of the Russian Academy of Sciences, especially the history of expeditions of the Russian Academy of Sciences in the first half of the $19^{\text {th }}$ century, focusing on the documentary part of the expedition work of Russian explorers. 